NBER WORKING PAPER SERIES

\title{
IS FOREIGN DIRECT INVESTMENT A CHANNEL OF KNOWLEDGE SPILLOVERS? EVIDENCE FROM JAPAN'S FDI IN THE UNITED STATES
}

\author{
Lee Branstetter
}

Working Paper 8015

http://www.nber.org/papers/w8015

\author{
NATIONAL BUREAU OF ECONOMIC RESEARCH \\ 1050 Massachusetts Avenue \\ Cambridge, MA 02138 \\ November 2000
}

I would like to thank Natasha Hsieh, Yoko Kusaka, Kentaro Minato, and especially Kaoru Nabeshima for excellent research assistance. I also thank Robert Feenstra, Takatoshi Ito, Adam Jaffe, James Rauch, Mariko Sakakibara, and seminar participants at Brandeis University, Columbia University, Cornell University, UCSan Diego, and the April 1999 meeting of the NBER International Trade and Investment Program for valuable comments. Funding was provided by a University of California Faculty Research Grant, a grant from the Japan Foundation Center for Global Partnership, and the NBER Project on Industrial Technology and Productivity. Note that parts of this paper borrow heavily from Branstetter (2000). I am solely responsible for any errors. The views expressed in this paper are those of the author and not necessarily those of the National Bureau of Economic Research.

(C) 2000 by Lee Branstetter. All rights reserved. Short sections of text, not to exceed two paragraphs, may be quoted without explicit permission provided that full credit, including $\mathbb{C}$ notice, is given to the source. 
Is Foreign Direct Investment a Channel of Knowledge Spillovers?

Evidence from Japan's FDI in the United States

Lee Branstetter

NBER Working Paper No. 8015

November 2000

JEL No. F2, O3, L2

\begin{abstract}
Recent empirical work has examined the extent to which international trade fosters international "spillovers" of technological information. FDI is an alternate, potentially equally important channel for the mediation of such knowledge spillovers. I introduce a framework for measuring international knowledge spillovers at the firm level, and I use this framework to directly test the hypothesis that FDI is a channel of knowledge spillovers for Japanese multinationals undertaking direct investments in the United States. Using an original firm-level data set on Japanese firms' FDI and innovative activity, I find evidence that FDI increases the flow of knowledge spillovers both from and to the investing Japanese firms.
\end{abstract}

Lee Branstetter

Department of Economics

One Shields Avenue

University of California

Davis, CA 95616

and NBER

branstet@ucdavis.edu 


\section{Introduction}

To what extent does technological knowledge flow across national borders, and by what means are these knowledge flows mediated? These questions have received an increasing amount of attention over the last decade, as some of the leading scholars in international economics have focused considerable research effort on the broad topic of knowledge spillovers. Ethier (1982), Rivera-Batiz and Romer (1991), Feenstra (1996), and, perhaps most notably, Grossman and Helpman (1990, 1991), among others, helped place this general subject in the forefront of international economic research with their pathbreaking work on models of endogenous innovation-driven growth and trade.

Incorporating technological progress into trade models can make a real difference, at least in theory. Technological considerations can expand the gains from trade. Liberal trade policies provide domestic entrepreneurs with the possibility of exploiting global markets rather than merely national ones; inducing more R\&D (or greater specialization); and generating higher levels of economic growth or welfare. Moreover, imported manufactured goods can -- in some of these models -- serve as channels of knowledge spillovers. ${ }^{1}$ Domestic firms can "learn from" the foreign goods they purchase by reverseengineering the technological innovations embodied in these goods. In this way, the "knowledge stock" on which domestic innovators can build is enlarged through liberal trade. ${ }^{2}$ While less thoroughly explored in formal models, the literature also suggests the possibility of a "learning-by-exporting" effect in which firms learn to improve the quality

\footnotetext{
${ }^{1}$ For empirical work on this possible channel of international knowledge spillovers, see Coe and Helpman (1995), and Keller (1997).

${ }^{2}$ Technological considerations can also complicate the gains from trade. If knowledge spillovers are national rather than international in scope, then comparative advantage itself can become path dependent, and an "accident of history" or a temporary policy that provides one country with a temporary advantage in an R\&D-intensive sector can have long-lasting implications for trade. See Grossman and Helpman (1991).
} 
of their products and production processes through contact with more advanced foreign competitors in global export markets. ${ }^{3}$

The flow of goods is not the only means through which technological knowledge can flow across national boundaries. An obvious alternative is foreign direct investment. A number of countries have policies that encourage or even subsidize multinational investment. Often, as is the case in Singapore and Malaysia, these policies are deliberately biased in favor of multinational firms in "technology intensive" industries. These preferential policies are based at least partly on the view that production and/or research activities undertaken by multinational affiliates within national borders confer “spillover" benefits. This view receives some support from the managerial literature. A series of research reports undertaken by the McKinsey Global Institute has consistently emphasized the importance of FDI as a channel for the international diffusion of "best practice" technology and management practices. ${ }^{4}$ In his widely cited work, Michael Porter has also emphasized the importance of this channel. ${ }^{5}$

In an effort to submit these views to careful statistical tests, Ann Harrison, Magnus Blomstrom, and others have undertaken empirical studies of "spillover" benefits from FDI. The work of Harrison and her co-authors, which has been particularly influential, has used micro-level panel data drawn from Morocco and Venezuela. ${ }^{6}$ While these papers do not explicitly model knowledge spillovers, their presence is inferred from changes in the productivity of "indigenous plants" that are associated with the "arrival"

\footnotetext{
${ }^{3}$ For empirical work on the "learning by exporting" channel, see Bernard and Jensen (1999), Clerides, Lach, and Tybout (1998), and Aw, Chen, and Roberts (1997).

${ }^{4}$ See, for example, McKinsey Global Institute (1993).

${ }^{5}$ See Porter (1990). In a related study, Kuemmerle (1997) examines the impact of establishing R\&D facilities abroad.

${ }^{6}$ See Aitken and Harrison (1999) and Haddad and Harrison (1993). A number of other studies, such as Eaton and Tamura (1996), use aggregate or industry-level data to examine these and related issues.
} 
of foreign manufacturing affiliates. These studies have generally failed to find robust evidence of positive knowledge spillovers from multinational investment. ${ }^{7}$

This paper also examines the role FDI plays in mediating knowledge spillovers, but does so in a very different economic context and takes a completely different methodological approach. First, I examine Japanese FDI in the U.S., rather than in a developing country. The motivations for this kind of FDI as well as its economic effects could be quite different from FDI in Morocco or Venezuela. ${ }^{8}$ Second, I do not follow the earlier convention of using measured changes in TFP or other revenue-based measures to infer the presence or absence of knowledge spillovers. As is well known, conventional measures of productivity can reflect market power as well as technical efficiency. When technologically more advanced foreign affiliates first enter a market, their presence may erode the market power of indigenous incumbents while -- at the same time -- introducing new production techniques and technologies from which these same incumbents learn. Real knowledge spillovers can take place, yet their effects can be masked in the data by changes in "appropriability conditions."

This paper presents an alternative empirical framework for measuring the impact of foreign direct investment on knowledge spillovers using patent citations data. I then use this framework to measure the impact of foreign direct investment in the United States by a group of Japanese manufacturing firms on knowledge flows from American firms to these investing Japanese firms and from the investing Japanese firms to

\footnotetext{
${ }^{7}$ Related work by Chung, Mitchell, and Yeung (1996) casts further doubt on the role of FDI as a channel of knowledge spillovers. However, see also Blomstrom et. al. (1995), who provide evidence for a more positive view of FDI as a channel of knowledge spillovers.

${ }^{8}$ Note that most FDI consists of investment from advanced industrial economies to other advanced industrial economies.
} 
American inventors. I find evidence foreign direct investment enhances knowledge flows in both directions.

\section{Empirical Methodology}

Using Patent Citations Data to Infer Knowledge Spillovers

In describing the approach taken in this paper, I need to carefully define what I mean by the term "knowledge spillovers." When I use this term, I refer to the process by which one inventor learns from the research outcomes of others' research projects and is able to enhance her own research productivity with this knowledge without compensating the other inventors. In other words, I am referring to the kinds of classic technological externalities that are at the core of the endogenous growth literature. A true knowledge spillover, by my definition, is something that generates further innovation. I make a conceptual distinction between knowledge spillovers per se and the related processes of "imitation" or "technology diffusion," though it is clear these phenomena overlap in practice. $^{9}$

Patent documents provide a potentially rich source of information on knowledge spillovers. Every U.S. patent applicant is required to include appropriate citations to the "prior art" in his or her application. By explicitly identifying the "prior art" on which the inventor builds, these citations serve the important legal function of bounding the innovation protected by the patent document. Just as academic researchers are expected to explicitly acknowledge the ideas and findings of others that they use in their own research (or be open to charges of plagiarism), so patent applicants are expected to

\footnotetext{
9 By restricting the focus of my paper to knowledge spillovers, I am necessarily taking a narrower approach than have some other papers in this literature, and I freely acknowledge that this narrower approach excludes much which is of economic interest.
} 
identify the prior art on which they build (or be open to charges of patent infringement). ${ }^{10}$ By examining the citations in corporate patent documents, one can see the innovations the inventors consider to be the "technological antecedents" of their own inventions. ${ }^{11}$

The legal function citations play in delineating the scope of the intellectual property rights conferred by a patent creates strong incentives for inventors to get the number and nature of citations right. The cost of citing a friend in a scientific paper is minimal, so it may frequently take place even when little or no knowledge spillover has taken place. The cost of extraneous citations in a patent document can be substantial, because they narrow the scope of the patent by explicitly placing related inventions outside the scope of the current patent application. As Jaffe, Trajtenberg, and Henderson (1993) put it, including extraneous citations is "leaving money on the table." Likewise, not including appropriate citations can expose a patent applicant to patent infringement lawsuits or to sanctions by the U.S. Patent and Trademark Office.

The use of patent citations to measure knowledge spillovers has been pioneered by Adam Jaffe, Manuel Trajtenberg, and Rebecca Henderson. In their 1993 paper, these three researchers used patent citations to measure the extent to which knowledge spillovers within the United States are geographically localized. In a series of working papers, Jaffe and Trajtenberg have used patent citations to compare magnitudes of knowledge flows across countries and across technological fields. ${ }^{12}$ Until now, however,

\footnotetext{
${ }^{10}$ This analogy, while illustrative, is far from exact. Jaffe, Fogarty, and Banks (1998) find that some patent citations are added by either the applicant or the patent examiner for legal or procedural reasons which have nothing to do with "knowledge spillovers." Nevertheless, they also found strong evidence that patent citations do indeed reflect patterns of knowledge spillovers, albeit with some "noise."

11 The points in this paragraph have been made and substantiated by Jaffe and his various co-authors, and some of the language here closely follows Jaffe, Fogarty, and Banks (1998).

${ }_{12}$ See Jaffe and Trajtenberg (1996). The contributors to this literature have also pointed out a number of problems with patent citation data. Among these is the simple fact that not all important innovations are patented.
} 
no one has used patent citations to investigate whether FDI aids or abets flows of

knowledge across national borders. ${ }^{13}$ This paper takes such an approach. ${ }^{14}$

\section{Estimating the Impact of FDI on Knowledge Spillovers}

Let $C_{J i t}$ be the number of citations made by the patent applications Japanese firm $i$

filed in year $t$ to the cumulated stock of "indigenous" U.S.-invented patents granted as of year $t .{ }^{15} \mathrm{I}$ can then write the expectation of $C_{J i t}$ as a function of several other observables

$$
E\left[C_{J i t}\right]=\left(N_{J i t}\right)^{\beta_{1}}\left(N_{A t}\right)^{\beta_{2}}\left[e^{\beta_{3} F D I_{i t}}\right]\left[e^{\beta_{4} P R O X_{i}}\right] R_{i t}{ }^{\beta_{5}} \alpha_{i} \alpha_{t}
$$

Let $E$ be the expectations operator. Here $\mathrm{E}\left[C_{J i t}\right]$ is a function of the number of patents Japanese firm $i$ has taken out in the U.S. in year $t\left(N_{J i t}\right)$, the number of potentially cited indigenous U.S. patents which exist as of year $t\left(N_{A t}\right)$, the level of firm $i$ 's "FDI presence" in the U.S. in year $t\left(F D I_{i t}\right)$, and the extent to which firm $i$ is at a point in the technology space which is "densely populated" by other indigenous U.S. patents $\left(P R O X_{i}\right)$. Some Japanese firms might cite U.S. patents more frequently simply because they happen to be working on technologies in which a large number of indigenous U.S. inventors are active.

If one wishes to control for this "technological proximity," the existing literature suggests a way in which it could be done. The typical Japanese firm in this data set

13 This statement needs qualification, in that two papers examine closely related topics. Almeida (1996) examines the citations in patents generated by a small number of foreign semiconductor affiliates. Frost (1995) examines the patent citations generated by a larger number of multinational affiliates across a broader range of industries. However, neither paper examines the impact of foreign direct investment on the R\&D of the parent firm, as I do in this paper. This distinction is quite important because, as Rene Belderbos (1999) has shown, only a tiny fraction of Japanese firms' total R\&D and patenting is conducted through their overseas subsidiaries. These subsidiaries may nevertheless play an important role in fostering knowledge spillovers if they affect the nature of $R \& D$ conducted by the parent company. This paper directly assesses the magnitude of that effect.

14 Note that all inference will be based on citations from and to the U.S. patents of Japanese firms. For a discussion on why this is appropriate, see the Data Appendix. The Data Appendix also describes how the U.S. patents of Japanese firms are distinguished from the U.S. patents of "indigenous" American inventors. 
conducts $\mathrm{R} \& \mathrm{D}$ in a number of technological fields simultaneously. One could obtain a measure of a firm's location in "technology space" by measuring the distribution of its R\&D effort across various technological fields. Let firm $i$ 's R\&D program be described by the vector $F$, where

$F_{i}=\left(f_{1}, \ldots, f_{k}\right)$

and each of the $k$ elements of $F$ represent the firm's research resources and expertise in the $k$ th technological area. ${ }^{16}$ From the number of patents taken out in different technological areas, I can infer what the distribution of R\&D investment and technological expertise across different technical fields has been.

In the same way, I can also compute a vector of location in technology space for the aggregate of all U.S. inventors, treating them as though they belonged to a single giant enterprise, and denoting that $F_{U S}$. This suggests that $P R O X_{i}$ might be measured as:

$$
\operatorname{PROX}_{i}=\frac{F_{i} F_{U S}^{\prime}}{\left[\left(F_{i} F_{i}^{\prime}\right)\left(F_{U S} F_{U S}^{\prime}\right)\right]^{1 / 2}}
$$

This is a technological proximity coefficient in the spirit of Jaffe (1986).

One may also wish to allow citations to be influenced by the firms' R\&D spending $\left(R_{i t}\right)$ and by vectors of multiplicative "fixed effects" associated with the citing firm $\left(\alpha_{i}\right)$ and the (application) year in which the citation takes place $\left(\alpha_{t}\right)$. Including these fixed effects actually simplifies the equation, provided one is willing to make some assumptions. The stock of cumulated potentially citable "indigenous" U.S. patents will

\footnotetext{
${ }^{15}$ Note that the U.S. Patent and Trademark Office only makes available data on patent applications that are eventually granted. In this paper, patents are dated by year of application rather than year of grant, because it takes on average two years - sometimes much longer - for the patent office to grant a patent.

${ }^{16}$ The $k$ different technological clusters are constructed by aggregating the hundreds of patent classes in the U.S. Patent and Trademark Office classification system into 50 distinct categories of technology. I then
} 
be the same for all Japanese citing firms in each year, so that the $N_{A t}$ terms are effectively absorbed into the time dummies. One may also want to assume that a firm's location in technology space relative to aggregate American inventive activity is relatively fixed over time. In that case, the effect of the $P R O X$ measure is absorbed into the firm fixed effects. ${ }^{17}$ The fact that I cannot separately identify it from the firm effects is of little concern, as my primary focus is on the impact of changes in FDI on citations.

Taking the log of (1) and implementing these assumptions gives us a simple, loglinear estimation equation

$c_{J i t}=\beta_{0}+\beta_{1} p_{i t}+\beta_{2} F D I_{i t}+\beta_{3} r_{i t}+\sum_{t} \alpha_{t} T_{t}+\alpha_{i}+\varepsilon_{i t}$

where $c_{j i t}$ is the $\log$ of the number of citations made by the U.S. patent applications of Japanese firm $i$ in year $t$ to indigenous U.S. patents, $p$ is the $\log$ of the count of U.S. patent applications of Japanese firm $i$ in year $t$, FDI is one of a number of alternative measures of the FDI stock of firm $i$ in year $t, r$ is the $\log$ of R\&D spending of firm $i$ in year $t$, the $\alpha_{t}$ 's are time dummies, and $\alpha_{i}$ is a "firm effect," reflecting firm-specific research productivity and, perhaps, firm-specific but time invariant differences in the "connectedness" of the Japanese firm's research team to current developments in U.S. research that might affect its tendency to cite U.S. patents.

The assumption that the technological proximity of a Japanese firm to U.S. inventive activity stays fixed over a long period is a strong one. The data permit me to allow this proximity measure to vary within firms over time, although I lack sufficiently rich patent data to do this for all firms or all years. If firms are simultaneously increasing

count the number of patents taken out by firm $i$ in each of these 50 categories over full length of my sample period. 
their FDI in the U.S. and moving "closer" to U.S. firms in technology space, this new specification allows me to control for the latter effect, picking up only the partial effect of an increase in FDI on "spillovers" as measured by citations. ${ }^{18}$ This imposes a much more stringent statistical test of the impact of FDI on knowledge spillovers. After all, it is possible some of the movement of Japanese firms in "technology space" is induced by spillovers from American firms, which they receive through their network of subsidiaries. However, if a positive effect of FDI remains even after controlling for this movement, this is even stronger evidence in favor of the view that FDI is a channel of knowledge spillovers. The specification suggested by this line of thinking would be:

$c_{J i t}=\beta_{0}+\beta_{1} p_{i t}+\beta_{2} F D I_{i t}+\beta_{3} r_{i t}+\beta_{4} P R O X_{i t}+\sum_{t} \alpha_{t} T_{t}+\alpha_{i}+\varepsilon_{i t}$

If citations measure spillovers, and if spillovers increase the research productivity of the firm, then one might think some of that increased research productivity would show up in increased levels of U.S. patenting. This implies $p_{i t}$ depends on lagged and, perhaps, current values of $c_{J i t}$. If the spillover effects are sufficiently strong and the spillover lags are sufficiently short, this could create an identification problem. The appropriate solution to this problem is to formally model the dependence of $p_{i t}$ on $c_{J i t}$ and estimate that equation as well as (5) as a system. I have not taken that step, largely due to the lack of sufficient information on the "reverse" relationship between the two variables.

17 "Industry effects" will also be absorbed into the firm effects, because firms in my sample do not change their primary industry affiliation over time.

18 Suppose Fujitsu decides to become a world leader in "wireless modems." Fujitsu will need to establish distribution and, possibly, manufacturing facilities in America because it is a leading national market for this kind of product. At the same time, Fujitsu will begin to conduct more research on technologies related to wireless modems and take out more patents protecting its research in this area. Since many American firms have been active in this technology, Fujitsu's new patents will inevitably cite American patents quite frequently. In this case, a change in firm strategy generates both an increase in U.S. FDI and an increase in citations to U.S. patents, though there is no direct causal relationship between the two variables. Without controlling for the firm's movement in technology space, one could overestimate the impact of FDI on knowledge spillovers. 
As an expedient partial remedy, I substitute one-period lagged patents, which I (plausibly) assume not be influenced by future spillovers, into my empirical specifications in place of contemporaneous patents.

The focus of interest will be on the coefficient $\beta_{2}$. Do firms that increase their levels of FDI in the United States experience an increased tendency to cite U.S. patents? ${ }^{19}$ A positive, significant coefficient would suggest the answer is yes. The reason why one might expect a positive coefficient is straightforward. To monitor and understand other firms' $R \& D$ can be a difficult task - particularly when the other firms' R\&D activities are located on the opposite side of the Pacific Ocean. It may be facilitated enormously by the geographical proximity attained through FDI, through which the cost of accessing foreign firms' knowledge assets is reduced. This effect may occur regardless of whether or not the FDI by the Japanese firm takes the form of "greenfield" new investment or acquisition of existing U.S. firms.

However, there are also both theoretical and empirical reasons for thinking the spillover-enhancing effects of acquisition FDI and "greenfield" FDI are different. The “internalization" theory of FDI suggests firms establishing greenfield investments abroad may be exploiting firm-specific technological (and other) assets not possessed by their foreign competitors. Thus, Japanese firms establishing new production facilities in the United States may have relatively little to learn from their less technologically advanced American counterparts. On the other hand, Kogut and Chang $(1991,1996)$, Yamawaki (1993), and Blonigen (1997) have all found evidence suggesting that Japanese acquisitions in the United States are motivated -- at least in part -- by the desire to

\footnotetext{
19 It may be that an acquisition or greenfield investment might not have an immediate impact on the research of the Japanese parent firm, so various lags of the FDI "stock" will be considered.
} 
"access" American technological strengths. ${ }^{20}$ In light of this, I will present results based on total FDI as well as "acquisition" FDI only. ${ }^{21}$ Note that I am taking a broader view of the potential spillover benefits of acquisition than others have taken in this literature. I hypothesize that by purchasing a firm in the United States, Japanese firms potentially acquire not only the proprietary knowledge assets of the acquired firm but also entrée into the informal technological networks and knowledge sharing relationships possessed by the research personnel of the acquired firm. ${ }^{22}$

Of course, for Americans, the question of greater interest may be not what the Japanese firms have learned through their investments, but what indigenous American inventors have gained from a greater Japanese "presence" in the United States. A simple way to measure this through patent citations is to define a new dependent variable, $C_{A i t}$, as the number of citations made to the cumulated stock of U.S. patents of Japanese firm $i$ in year $t$ by the universe of indigenous U.S.-invented patents applied for in year $t$. I can then consider $C_{A i t}$ to be a function of observables and unobserved firm characteristics:

$$
E\left[C_{A i t}\right]=\left(N_{J i t}\right)^{\beta_{1}}\left(N_{A t}\right)^{\beta_{2}}\left[e^{\beta_{3} F D I_{i t}}\right]\left[e^{\beta_{4} P R O X_{i t}}\right]\left[e^{\beta_{5} A g e_{i t}}\right] R_{i t}^{\beta_{6}} \alpha_{i} \alpha_{t}
$$

where the variables have the same definitions as in (1), except for $N_{J i t}$ and $N_{A t}$. Here $N_{J i t}$ stands, not for the number of patents applied for by Japanese firm $i$ in year $t$, but rather the cumulative stock of patents of Japanese firm $i$ as of year $t$. This is because the

\footnotetext{
20 Wesson (1998) also finds evidence for "asset-seeking" FDI.

21 Because of the richness of my FDI data, I also can (and do) separately examine the impact of Japanese firms' U.S. R\&D and product engineering facilities on spillovers.

${ }^{22}$ This discussion raises the question of how I should treat Japanese firms' citations of the U.S. patents of their acquired subsidiaries and, conversely, the citations by the acquired subsidiaries to the U.S. patents of the Japanese parents. It would hardly be surprising to see such citations - in both directions - increase after an acquisition. However, this would not be evidence of a "spillover" in the sense that unaffiliated U.S. firms are receiving and providing greater technological externalities vis-à-vis the Japanese parent firms as a consequence of an increase in the "FDI presence" of those parent firms. In recognition of this, I will present results both with and without citations to and from acquired subsidiaries. This does not change the qualitative nature of my conclusions. I thank Jim Rauch for discussions on this point.
} 
number of citations a Japanese firm receives in a given year is likely to be a function of its cumulative stock of U.S. patents rather than the number of applications taken out in a particular year. $N_{A t}$ stands for the number of potentially citing U.S. patents in year t, which will be the same for all sample firms in a given year. I have also added a variable, Age, which is described below.

In their detailed studies of patent citations, Adam Jaffe and his co-authors have found that it takes time for the knowledge contained in patents to diffuse, such that patent citations initially increase over time. As time passes, the knowledge contained within patents becomes obsolete, so that patent citations have a tendency to decrease over longer lengths of time. Since, in some specifications, I want to control for differences in the "citedness" of different Japanese firms that are driven by differences in the age distribution of their patent stocks rather than FDI, I will include for each Japanese firm in each year for which I have sufficient data a summary statistic of the age distribution of their U.S. patent stocks, denoted $A g e^{23}$

As in equation (4), I begin by assuming the relative technological proximity of firm $i$ to aggregate American inventive activity is fixed over time, take the logs, and generate a log-linear estimating equation:

$c_{A i t}=\beta_{0}+\beta_{1} p_{i t}+\beta_{2} F D I_{i t}+\beta_{3} r_{i t}+\sum_{t} \alpha_{t} T_{t}+\alpha_{i}+\varepsilon_{i t}$

where the variables have the same definitions as in (4), with the exception that $p_{i t}$ now stands for the cumulative stock of patents of firm $i$ as of year $t$. Again, my interest will focus on $\beta_{2}$. Do U.S. inventors' citations to the patents of a Japanese firm increase as

\footnotetext{
${ }^{23}$ Work by Jaffe and his coauthors suggests that the frequency of citation for a given patent peaks on average 4-6 years after the granting of the patent. This summary statistic measures the fraction of the U.S. patent stock for Japanese firm $i$ in year $t$ which is at this "prime" age.
} 
the FDI presence of that firm increases? A positive, significant $\beta_{2}$ would indicate this. Relaxing the assumption of "fixed" technological proximity and controlling for changes in the age distribution of Japanese firms' patent stocks suggests a slightly more complicated specification:

$c_{A i t}=\beta_{0}+\beta_{1} p_{i t}+\beta_{2} F D I_{i t}+\beta_{3} r_{i t}+\beta_{4}$ Age $_{i t}+\beta_{5} P R O X_{i t}+\sum_{t} \alpha_{t} T_{t}+\alpha_{i}+\varepsilon_{i t}$

As a statistical matter, when one attempts to estimate (4), (5), (7), or (8), one finds there are a number of observations for which the dependent variable is 0 , and hence, the $\log$ of the dependent variable is undefined. There are two ways to address this problem. The first and simplest, which is standard in the older " $\mathrm{R} \& \mathrm{D} /$ productivity" literature, is to add 1 to each observation, then take the log. This raises the concern that this arbitrary transformation of the dependent variable could somehow bias the results. The alternative is to use an econometric model especially designed for count data, in which 0 is a natural outcome, such as a Poisson or Negative Binomial model. In this paper, I have taken the latter approach. ${ }^{24}$

Qualitative Evidence from Practitioner Interviews

In order to obtain a "practitioner's perspective" on the extent to which FDI functions as a channel of knowledge spillovers, I conducted a series of interviews with Japanese industry observers, government officials at the Ministry of International Trade and Industry (the government agency charged with overseeing the foreign direct investment activities of Japanese firms), and Japanese executives based in the United

\footnotetext{
${ }^{24}$ The basic frameworks of the Poisson and Negative Binomial models are laid out in the Data Appendix. Results obtained using linear models with a transformed dependent variable also find that FDI has a significant impact on knowledge spillovers, but the exact nature of that measured impact differs slightly from the results reported here. The results based on linear models are presented in the Data Appendix.
} 
States. These interviews were conducted in the fall of 2000, and are therefore somewhat removed in time from my quantitative data, which end in 1994.

All interviewees agreed with the view that foreign direct investment in the United States facilitates knowledge spillovers, as I have defined that term in this paper. It was also clear from discussions with the managers of Japanese research facilities in the U.S. that a major priority of at least some of these facilities is "tracking" U.S. technological developments in universities and among the leading firms. ${ }^{25}$ However, the interviewees also suggested that useful technology is absorbed by U.S. affiliates that are not "pure" research organizations. They agreed with the view that Japanese technology "leaks out" through their U.S. subsidiaries. In fact, this "leakage" is sometimes deliberately fostered by the Japanese firms. One Japanese R\&D manager based in Silicon Valley described a symposium his company had recently sponsored to publicize some of the firm's more basic R\&D. This was done in order to "engage" the local research community, enhance his firm's reputation among local engineers, and assist the firm in forming research partnerships with local academic experts.

Japanese firms make an effort to maintain a reasonably high degree of communication and coordination between their central R\&D operations and their U.S. R\&D facilities. One manager of such a facility claimed to communicate on a daily basis with the parent company and to physically travel to Japan several times per year for conferences with central R\&D managers. The same manager claimed that his firm sends

\footnotetext{
The differences may be driven, in part, by the necessary transformation of the dependent variable in the linear results.

${ }^{25}$ A particularly effective method of "tapping into" U.S. technological developments is to hire engineers, technology managers, and research scientists away from leading American firms and universities. This is a high priority for many Japanese research facilities, but also a continuing challenge. Many traditional Japanese labor market practices, such as lifetime employment, seniority based wages, slow promotion
} 
large numbers of engineers from the Japanese parent company to U.S. facilities each year on short term visits, essentially to promote knowledge spillovers. At the same time, many interviewees expressed the belief that these channels of communication could and should be made to work even more effectively.

A number of Japanese corporate interviewees expressed the view that the central $R \& D$ laboratories of Japanese firms have become bureaucratic, insular, and inefficient. Many expressed admiration for what they viewed as the much more market-oriented, dynamic "start-up" system in areas like Silicon Valley. Every Japanese firm I interviewed is attempting to use its research facilities in the United States as a base from which to seek out strategic partnerships and technology-sharing relationships with American high-tech start-ups in an attempt to increase the efficiency of their total R\&D operation. ${ }^{26}$ It remains to be seen whether or not these attempts will be successful. Privately, several Japanese corporate interviewees expressed concern that they would have great difficulty achieving this goal. Nevertheless, for now, the "traditional model" of relying primarily on internal technology development efforts has been revised to emphasize greater technological integration with U.S.-based strategic partners. This seems to suggest that the U.S. subsidiaries of Japanese firms - especially the research facilities - will play an even more central role as a channel of knowledge spillovers in the future than they have in the past.

tracks, and consensus-style decisionmaking, do not fit well with the more entrepreneurial culture of such U.S. technology centers as Silicon Valley.

${ }^{26}$ This pursuit of technology-sharing relationships goes beyond high-tech start-ups. Technology sharing relationships are also cultivated with leading established U.S. firms, such as Hewlett-Packard, IBM, and Oracle. One firm also claims that its European research affiliates are actively involved in EU-sponsored research consortia. 


\section{Empirical Results}

Data on Japanese firms' sales were taken from the Japan Development Bank Corporate Finance Database. R\&D data were collected from various issues of the Kaisha Shiki Ho series, and data on FDI were taken from the Kaigai Shinshutsu Kigyou Souran, 1997 edition, both published by Toyou Keizai. Patent data were obtained from the U.S. Patent and Trademark Office and the REI database at Case Western Reserve University. Further details on data sources and construction are available from the author upon request. Some sample statistics are given in Table 1. Note that data on FDI consists of counts of firms acquired or established in the U.S. Unfortunately, the nature of the data prevents me from weighting these counts by the size of the establishment. ${ }^{27}$

Results for citations by the patents of Japanese firms to the stock of U.S. patents are given in Table 2. This measures knowledge spillovers to Japanese firms from U.S. inventors. In all specifications, real sales was added as an additional control variable. The designation of specifications as (1), (2), and (3) refers to three alternative measures of FDI. (1) counts the cumulative sum of total affiliates, regardless of the means of establishment or the purpose of the affiliate. (2) counts only the cumulative sum of affiliates obtained through acquisition. (3) counts only the cumulative sum of affiliates whose "statement of business purpose" in the FDI database explicitly identifies it as an overseas R\&D facility. ${ }^{28}$

In fixed effects Poisson and Negative Binomial models, there is a statistically significant positive relationship for two measures of FDI - acquisition FDI and R\&D

\footnotetext{
27 For a discussion of these measurement issues, see the Data Appendix.

${ }^{28}$ Although not shown in the table, I experimented with various lags of the FDI variables. I found the results of the lags were qualitatively similar to, but statistically weaker than, the results of contemporaneous
} 
facilities. ${ }^{29}$ The impact of "broadly defined" FDI is positive, but not statistically significant. The coefficient on the FDI term has a "semi-elasticity" interpretation. For example, the number in the sixth column suggests that setting up an additional R\&D lab in the U.S. leads to a $2.3 \%$ increase in spillovers from U.S. inventors. The reported log likelihood numbers suggest that the Negative Binomial model provides a better fit to the data. Henceforth, only Negative Binomial results will be presented.

Table 3 shows results for U.S. citations to Japanese patents, which measure knowledge spillovers from Japanese firms to U.S. inventors. The results in the table are obtained using 2-period lagged measures of FDI. ${ }^{30}$ The measured impact of total FDI on knowledge spillovers is positive and statistically significant. Counts of $R \& D$ facilities do not have a statistically significant effect. Although the measured impact of acquisition FDI is larger than total FDI in terms of its absolute magnitude, it is not statistically significant at the conventional levels.

Tables 4 and 5 provide a robustness check on the earlier results by incorporating a time-varying measure of the technological proximity of Japanese firms with respect to U.S. invention. Furthermore, in these regressions, all citations to and from acquired U.S. subsidiaries are deleted from the total counts. Table 4 measures spillovers to Japanese firms using a fixed effects Negative Binomial estimate of equation (5). The results are broadly similar to those presented in Table $2 .^{31}$ The reader will note that FDI has a positive and statistically significant effect on spillovers, as evidenced by the $F D I$

measures. This may indicate that spillovers to investing Japanese firms occur quickly after the acquisition or "greenfield" establishment takes place.

${ }^{29}$ Acquisition FDI is only significant at the $10 \%$ level in the Negative Binomial fixed effects regressions. R\&D facilities are significant at the traditional $5 \%$ level.

${ }^{30}$ Contemporaneous FDI tends to have limited, generally statistically insignificant effects on spillovers from Japanese firms to U.S. inventors. 
coefficients presented in columns (1) and (3). The magnitude of the coefficient for "acquisition" FDI is the largest, but this coefficient falls below the conventional level of statistical significance.

Table 5 measures spillovers from Japanese firms using controls for both timevarying technological proximity and the changing age distribution of these Japanese firms' U.S. patent stocks. In introducing these additional controls, I lose a large number of observations. Nevertheless, column (1) clearly shows that (total) FDI has a positive and statistically significant effect on spillovers to the U.S. ${ }^{32}$ The impact of "acquisition" FDI is statistically indistinguishable from zero in these regressions, as is the impact of R\&D facilities only. ${ }^{33}$

To briefly summarize these results, the establishment of U.S. R\&D facilities tends to have a robust positive impact on spillovers to the investing Japanese firms, but little impact in the other direction. The "total" measure of FDI tends to have a positive impact on knowledge spillovers in both directions, and this holds in all specifications except those shown in Table 2. It is interesting to note that the absolute magnitude of the impact of acquisition on spillovers tends to be relatively large in all specifications, but the precision with which this coefficient is estimated tends to be quite low. This may be because my current measure of acquisition fails to distinguish between firms acquired for their "knowledge assets" (i.e., Kubota's 1987 acquisition of a Silicon Valley disk drive manufacturer) and firms acquired for other reasons (i.e., Kirin's 1988 acquisition of a

\footnotetext{
${ }^{31}$ Note that the inclusion of the additional controls cuts down the sample size - I lose about one quarter of the observations. A similar problem affects the results of Table 5 .

${ }^{32}$ As in Table 3, measures of FDI are lagged by two periods. However, results with contemporaneous measures of FDI are qualitatively very similar to those presented here.

33 The reader may note that, in many tables, the estimated coefficients on firm-level sales are negative. While these results run counter to what one might suspect, they may be driven by the multicollinearity in firms' total level of patenting, total R\&D spending, and total sales.
} 
winery in the California Napa Valley), thus generating a fair amount of "noise" in the data.

According to my regression results, the estimated marginal impact of an additional U.S. affiliate on spillover flows ranges from approximately $1 \%$ to $4 \%$. This sounds like a small effect, but the cumulative impact of a large increase in a firm's U.S. "FDI presence" could be substantial. Many sample firms establish and/or acquire dozens of U.S. affiliates over the course of the sample period. Multiplying this level of increase in a firm's FDI stock by my estimated marginal effects implies a relatively large increase in knowledge spillover flows.

\section{Conclusions and Extensions}

In this paper, I have used patent citations data to measure the importance of foreign direct investment in mediating flows of knowledge spillovers across national borders. In contrast to other recent micro-level studies, I find evidence that FDI is a significant channel of knowledge spillovers, both from investing firms to indigenous firms and from indigenous firms to investing firms. This evidence is broadly consistent with the perceptions of market participants, as discussed in Section II.

Strategy experts have long asserted that investing abroad can be a useful way of tapping into foreign technology networks. My study upholds this belief with quantitative data, emphasizing the potential importance of multinational corporations as channels of knowledge spillovers between advanced economies. While one needs to exercise caution in drawing general policy implications from these findings, my results suggest national restrictions on FDI could hamper rather than promote a domestic industry's technological development. 
Extending the framework presented in this paper to analyze the impact of Japanese exports to the United States on the ability of the exporting firms to "learn from" U.S. technological developments (the focus of the "learning by exporting" literature) is straightforward. One can simply insert measures of exports to the U.S. market into equation (1). Export data broken down by destination market are available for many Japanese firms. In principle, it should be feasible to place measures of exports and FDI into the same estimating equation, allowing the researcher to compare the impact of these two measures of international "connectedness" on knowledge spillovers. Likewise, the framework could be extended to measure the impact of Japanese exports to the United States (that is, imports of Japanese goods by American inventors) on the propensity of U.S. innovators to cite Japanese inventions. ${ }^{34}$

Although Japanese firms are collectively the most important foreign users of the U.S. patent system, large numbers of European firms also patent and invest heavily in the U.S. The framework presented in this paper could be utilized to measure the impact of FDI on knowledge spillovers between the U.S. and Europe. Finally, the framework used in this paper could potentially serve as the nucleus for a more complete model of the R\&D-intensive multinational firm that links information on knowledge spillovers derived from patent citations to other "innovative output" measures. Creating such a model is the focus of current research.

\footnotetext{
34 A specification that could measure "learning by exporting" would be something along the lines of $E\left[C_{J i t}\right]=\left(N_{J i t}\right)^{\beta_{1}}\left(N_{A t}\right)^{\beta_{2}}\left[e^{\beta_{3} F D I_{i t}}\right]\left[e^{\beta_{4} E X P O R T S_{i t}}\right] R_{i t}{ }^{\beta_{5}} \alpha_{i} \alpha_{t}$. Likewise, a specification measuring "learning by importing" would be $E\left(C_{A i t}\right)=\left(N_{J i t}\right)^{\beta_{1}}\left(N_{A t}\right)^{\beta_{2}}\left[e^{\beta_{3} F D I_{i t}}\right]\left[e^{\beta_{4} E X P O R T S_{i t}}\right] R_{i t}^{\beta_{5}} \alpha_{i} \alpha_{t}$.
} 


\section{Bibliography}

Aitken, Brian and Ann Harrison, (1999) "Do Domestic Firms Benefit from Foreign Direct Investment? Evidence from Venezuela" American Economic Review, Vol. 89 (3), pp. 605-618.

Aitken, Brian, Gordon Hansen, and Ann Harrison (1997), "Spillovers, Foreign Investment, and Export Behavior" Journal of International Economics, Vol. 43 (1-2), pp. 103-32.

Almeida, Paul (1996), "Knowledge Sourcing by Foreign Multinationals: Patent Citation Analysis in the U.S. Semiconductor Industry,” Strategic Management Journal, Vol. 17, pp. 155-165.

Aw, Bee, Xiaomin Chen, and Mark Roberts (1997), "Firm-level Evidence on Productivity Differentials, Turnover, and Exports in Taiwanese Manufacturing," NBER working paper no. 6235.

Belderbos, Rene (1999), "Overseas innovations by Japanese firms: A micro-econometrical analysis of patent and subsidiary data," working paper 99-1, Hitotsubashi University, Institute of Innovation Research.

Bernard, Andrew and J. Bradford Jensen (1999), "Exceptional Exporter Performance: Cause, Effect, or Both?" Journal of International Economics, Vol. 47 (1), pp. 1-25.

Blomstrom, Magnus, Ari Kokko, and Mario Zejan (1995), "Host Country Competition and Technology Transfer by Multinationals," NBER working paper no. 4131.

Blonigen, Bruce (1997), "Firm-Specific Assets and the Link Between Exchange Rates and Foreign Direct Investment," American Economic Review, Vol. 87 (3), pp. 447-465.

Branstetter, Lee (2000), "Foreign Direct Investment and R\&D Spillovers: Is there a Connection?" forthcoming in Takatoshi Ito and Anne Krueger, (eds), The Role of Foreign Direct Investment in Economic Development, University of Chicago Press.

Branstetter, Lee and Mariko Sakakibara (1998), "Japanese Research Consortia: A Microeconometric Analysis of Industrial Policy,” Journal of Industrial Economics, Vol. 46 (2), pp. 207-233.

Chung, Wilbur, Will Mitchell, and Bernard Yeung (1996), "Foreign Direct Investment and Host Country Productivity: The Case of the American Automotive Components Industry," manuscript, University of Michigan, School of Business Administration.

Clerides, Sofronis, Saul Lach, and James Tybout (1998), "Is Learning by Exporting Important? MicroDynamic Evidence from Colombia, Mexico, and Morocco," Quarterly Journal of Economics, vol. CXIII, no. 3, pp. 903-948.

Coe, David and Elhanan Helpman (1995), "International R\&D Spillovers," European Economic Review, 39(5), pp. 859-887.

Eaton, Jonathan and Akiko Tamura (1996), "Japanese and U.S. Exports and Investment as Conduits of Growth," Financial Deregulation and Integration in East Asia, edited by Anne O. Krueger and Takatoshi Ito. University of Chicago Press.

Ethier, Wilfred, (1982), "National and International Returns to Scale in the Modern Theory of International Trade," American Economic Review, Vol. 72 (3), pp. 389-405.

Feenstra, Robert, (1996), “Trade and Uneven Growth,” Journal of Development Economics, Vol. 49 (1), pp. 229-256. 
Frost, Tony (1995), "Multinationals and Spillovers of Technical Knowledge: A Comparative Institutional Analysis," working paper, MIT.

Grossman, Gene and Elchanan Helpman, (1991), Innovation and Growth in the Global Economy. The MIT Press, Cambridge.

Grossman, Gene and Elchanan Helpman, (1990), "Comparative Advantage and Long-run Growth," American Economic Review, Vol. 80 (4), pp. 796-815.

Haddad, Mona and Ann Harrison (1993), “Are There Positive Spillovers from Direct Foreign Investment? Evidence from Panel Data for Morocco," Journal of Development Economics, Vol. 42 (1), pp. 5174.

Hausman, Jerry, Bronwyn Hall, and Zvi Griliches (1984), "Econometric Models for Count Data with an Application to the Patents-R\&D Relationship," Econometrica, Vol. 52 (4), pp. 909-938.

Henderson, R., A. Jaffe, and M. Trajtenberg (1998), "Universities as a Source of Commercial Technology: A Detailed Analysis of University Patenting, 1965-1988," Review of Economics and Statistics, Vol. 80 (1), pp. 119-127.

Jaffe, Adam (1986), "Technological Opportunity and Spillover of R\&D: Evidence from Firms' Patents, Profits, and Market Value," American Economic Review, Vol. 76 (5), pp. 984-1001.

Jaffe, A., M. Trajtenberg, and R. Henderson (1993), "Geographic Localization of Knowledge Spillovers as Evidenced by Patent Citations," Quarterly Journal of Economics, Vol. 108 (3), pp. 577-598.

Jaffe, Adam, and Manuel Trajtenberg (1996), "Flows of Knowledge Spillovers From Universities and Federal Labs: Modeling the Flow of Patent Citations Across Institutional and Geographic Boundaries," NBER Working Paper 5712.

Jaffe, Adam, Michael Fogarty, and Bruce Banks, (1998), "Evidence from Patents and Patent Citations on the Impact of NASA and Other Federal Labs on Commercial Innovation," Journal of Industrial Economics, Vol. 46 (2), pp. 183-205.

Keller, Wolfgang, (1998), "Are international R\&D spillovers trade-related? Analyzing spillovers among randomly matched trade partners," European Economic Review, Vol. 42, pp. 1469-81.

Kogut, Bruce and Sea Jin Chang (1991), "Technological Capabilities and Japanese Foreign Direct Investment in the United States," Review of Economics and Statistics, Vol. 73, pp. 401-413.

Kuemmerle, Walter (1997), "Building Effective R\&D Capabilities Abroad," Harvard Business Review, March-April issue, pp. 61-70.

McKinsey Global Institute (1993), "Manufacturing Productivity,” McKinsey \& Company, Washington, D.C.

Montalvo, Jose and Yishay Yafeh (1994), "A Micro-Econometric Analysis of Technology Transfer: The Case of Licensing Agreements of Japanese Firms," International Journal of Industrial Organization, Vol. 12 (2), pp. 227-244.

Porter, Michael E. (1990), The Competitive Advantage of Nations, The Free Press, New York.

Rivera-Batiz, Luiz and Paul Romer, (1991) "Economic Integration and Endogenous Growth, " Quarterly Journal of Economics, Vol. 106 (2), pp. 531-555. 
Sakakibara, Mariko and Lee Branstetter (forthcoming), "Do Stronger Patents Induce More Innovation? Evidence from the 1988 Patent Law Reforms," Rand Journal of Economics.

Toyou Keizai Publishing Co. (1997), Kaigai Shinshutsu Kigyou Souran, Tokyo, Japan.

Toyou Keizai Publishing Co., various issues, Kaisha Shiki Ho, Tokyo, Japan.

Wesson, Tom (1998), “Asset-Seeking Foreign Direct Investment,” working paper, York University. 
Table 1 Sample Statistics for Japanese Firms

\begin{tabular}{lllll}
\hline Variable & Mean & St. Dev. & Min & Max \\
\hline Patents & 49.57 & 140.69 & 0 & 1178 \\
R\&D & $22,869.82$ & $53,793.95$ & 50 & $445,212.3$ \\
$\begin{array}{l}\text { Citations to U.S.- } \\
\text { invented patents }\end{array}$ & 106.45 & 325.38 & 0 & 2820 \\
$\begin{array}{l}\text { Citations by U.S.- } \\
\text { invented patents }\end{array}$ & 89.28 & 312.91 & 0 & 4348 \\
Sales & $351,525.6$ & $741,148.2$ & $2,720.623$ & $9,025,592$ \\
U.S. affiliates & 1.44 & 2.68 & 0 & 35 \\
\hline
\end{tabular}

Units of sales and R\&D figures are millions of 1990 Japanese yen.

Table 2 Spillovers to Japanese Firms

Poisson and Negative Binomial Regressions Dependent Variable: Citations $\quad$ Obs $=2093$

\begin{tabular}{|c|c|c|c|c|c|c|}
\hline & $\begin{array}{l}\text { Fixed } \\
\text { Effects }(1)\end{array}$ & $\begin{array}{l}\text { Fixed } \\
\text { Effects (2) }\end{array}$ & $\begin{array}{l}\text { Fixed } \\
\text { Effects(3) }\end{array}$ & $\begin{array}{l}\text { Fixed } \\
\text { Effects }(1)\end{array}$ & $\begin{array}{l}\text { Fixed } \\
\text { Effects(2) }\end{array}$ & $\begin{array}{l}\text { Fixed } \\
\text { Effects(3) }\end{array}$ \\
\hline & Poisson & Poisson & Poisson & NB & NB & NB \\
\hline $\log R \& D$ & $\begin{array}{l}.0446 \\
(.0098)\end{array}$ & $\begin{array}{l}.0452 \\
(.0098)\end{array}$ & $\begin{array}{l}.0450 \\
(.0098)\end{array}$ & $\begin{array}{l}.1143 \\
(.0327)\end{array}$ & $\begin{array}{l}.1160 \\
(.0328)\end{array}$ & $\begin{array}{l}.1215 \\
(.0329)\end{array}$ \\
\hline log sales & $\begin{array}{l}.3220 \\
(.0178)\end{array}$ & $\begin{array}{l}.3102 \\
(.0176)\end{array}$ & $\begin{array}{l}.2624 \\
(.0187)\end{array}$ & $\begin{array}{l}-.1842 \\
(.0238)\end{array}$ & $\begin{array}{l}-.1851 \\
(.0238)\end{array}$ & $\begin{array}{c}-.1871 \\
(.0238)\end{array}$ \\
\hline $\log$ U.S. patents & $\begin{array}{l}.6754 \\
(.0067)\end{array}$ & $\begin{array}{l}.6728 \\
(.0067)\end{array}$ & $\begin{array}{l}.6762 \\
(.0067)\end{array}$ & $\begin{array}{l}.8096 \\
(.0208)\end{array}$ & $\begin{array}{l}.8084 \\
(.0208)\end{array}$ & $\begin{array}{l}.8079 \\
(.0207)\end{array}$ \\
\hline U.S. FDI & $\begin{array}{l}.0006 \\
(.0008)\end{array}$ & $\begin{array}{l}.0351 \\
(.0053)\end{array}$ & $\begin{array}{l}.0136 \\
(.0015)\end{array}$ & $\begin{array}{l}.0031 \\
(.0035)\end{array}$ & $\begin{array}{l}.0427 \\
(.0246)\end{array}$ & $\begin{array}{l}.0227 \\
(.0065)\end{array}$ \\
\hline Time Dummies & Yes & Yes & Yes & Yes & Yes & Yes \\
\hline Log Likelihood & -13097.6 & -13075.7 & -13056.3 & -6519.8 & -6518.7 & -6514.4 \\
\hline
\end{tabular}

(1) Indicates FDI measured as cumulative counts of all U.S. subsidiaries.

(2) Indicates FDI measured as cumulative counts of acquired U.S. subsidiaries.

(3) Indicates FDI measured as cumulative counts of U.S. R\&D/product development facilities. 
Table 3 Spillovers from Japanese Firms

Negative Binomial Regressions

Dependent Variable: Citations $\quad$ Obs $=2006$

\begin{tabular}{|l|lll|}
\hline \multicolumn{1}{|c}{} & \multicolumn{1}{l}{ Fixed } \\
Effects(1) & $\begin{array}{l}\text { Fixed } \\
\text { Effects(2) }\end{array}$ & $\begin{array}{l}\text { Fixed } \\
\text { Effects(3) }\end{array}$ \\
\hline \multirow{4}{*}{$\log$ R\&D } & -.0306 & -.0286 & -.0287 \\
& $(.0197)$ & $(.0197)$ & $(.0197)$ \\
& -.1294 & -.1243 & -.1247 \\
$\log$ U.S. patents & $.0193)$ & $(.0193)$ & $(.0193)$ \\
& .8827 & .8754 & .8772 \\
U.S. FDI & $(.0283)$ & $(.0285)$ & $(.0285)$ \\
& & & \\
Time Dummies & $\mathbf{. 0 1 0 3}$ & $\mathbf{. 0 2 0 1}$ & $\mathbf{. 0 0 2 9}$ \\
Log Likelihood & $\mathbf{. 0 0 2 1 )}$ & $\mathbf{( . 0 1 5 1 )}$ & $\mathbf{( . 0 0 4 0 )}$ \\
& Yes & Yes & Yes \\
& & & \\
\hline
\end{tabular}

(1) Indicates FDI measured as cumulative counts of all U.S. subsidiaries.

(2) Indicates FDI measured as cumulative counts of acquired U.S. subsidiaries.

(3) Indicates FDI measured as cumulative counts of U.S. R\&D/product development facilities. 
Table 4 Spillovers to Japanese Firms

Negative Binomial Regressions,

Using a Time-Varying Measure of Technological Proximity

Dependent Variable: Citations $\quad$ Obs $=1,492$

\begin{tabular}{|l|lll|}
\hline \multicolumn{1}{|l}{} & \multicolumn{1}{l}{$\begin{array}{l}\text { Fixed } \\
\text { Effects(1) }\end{array}$} & $\begin{array}{l}\text { Fixed } \\
\text { Effects(2) }\end{array}$ & $\begin{array}{l}\text { Fixed } \\
\text { Effects(3) }\end{array}$ \\
\hline \multirow{4}{*}{$\log$ R\&D } & .095 & .094 & .104 \\
& $(.040)$ & $(.039)$ & $(.040)$ \\
& & & \\
$\log$ Sales & -.188 & -.187 & -.195 \\
& $(.030)$ & $(.030)$ & $(.030)$ \\
& & & \\
Time-varying Proximity & .655 & .657 & .660 \\
& $(.029)$ & $(.029)$ & $(.028)$ \\
U.S. FDI & 1.91 & 1.91 & 1.77 \\
& $(.323)$ & $(.325)$ & $(.322)$ \\
Time Dummies & & & \\
Log Likelihood & $\mathbf{. 0 0 8}$ & $\mathbf{. 0 4 6}$ & $\mathbf{. 0 3 0}$ \\
& $\mathbf{( . 0 0 4 )}$ & $\mathbf{( . 0 2 9 )}$ & $\mathbf{( . 0 0 8 )}$ \\
& Yes & Yes & Yes \\
& & & \\
& -4777.0 & -4777.4 & -4774.2 \\
& & & \\
\hline
\end{tabular}

(1) Indicates FDI measured as cumulative counts of all U.S. subsidiaries.

(2) Indicates FDI measured as cumulative counts of acquired U.S. subsidiaries.

(3) Indicates FDI measured as cumulative counts of U.S. R\&D/product development facilities. 
Table 5 Spillovers from Japanese Firms

Negative Binomial Regressions,

Using a Time-Varying Measure of Technological Proximity and

a Summary Statistic of the Age Distribution

Dependent Variable: Citations

\begin{tabular}{|l|lll|}
\hline \multicolumn{1}{|c}{} & $\begin{array}{l}\text { Fixed } \\
\text { Effects(1) }\end{array}$ & $\begin{array}{l}\text { Fixed } \\
\text { Effects(2) }\end{array}$ & $\begin{array}{l}\text { Fixed } \\
\text { Effects(3) }\end{array}$ \\
\hline \multirow{4}{*}{$\log$ R\&D } & -.009 & -.004 & -.005 \\
& $(.020)$ & $(.020)$ & $(.020)$ \\
& & & \\
log U.S. patents & -.155 & -.210 & -.209 \\
& $(.023)$ & $(.023)$ & $(.023)$ \\
Time-varying Proximity & .826 & .830 & .833 \\
& $(.034)$ & $(.040)$ & $(.037)$ \\
Age & 1.31 & 1.38 & 1.32 \\
& $(.323)$ & $(.334)$ & $(.333)$ \\
U.S. FDI & .903 & .814 & .842 \\
& $(.109)$ & $(.109)$ & $(.110)$ \\
Time Dummies & & & $\mathbf{. 0 0 6}$ \\
Log Likelihood & $\mathbf{. 0 0 9}$ & $\mathbf{. 0 1 9}$ & $\mathbf{( . 0 0 4 )}$ \\
& $\mathbf{( . 0 0 2 )}$ & $\mathbf{( . 0 1 5 )}$ & \\
& Yes & Yes & Yes \\
& & & \\
\hline
\end{tabular}

(1) Indicates FDI measured as cumulative counts of all U.S. subsidiaries.

(2) Indicates FDI measured as cumulative counts of acquired U.S. subsidiaries.

(3) Indicates FDI measured as cumulative counts of U.S. R\&D/product development facilities. 


\section{Data Appendix}

In order to keep the text of the paper reasonably short, I have omitted a number of details about data sources, data construction, the empirical methodology, and the results of alternative specifications. This Data Appendix describes the basic data sources in greater detail, presents some results from linear regression models that can be compared to the count data results presented in the text of the paper, and offers a sketch derivation of the count data models employed in the paper.

\section{Data Sources and Measurement Issues}

The primary source of data on the U.S. FDI of Japanese firms is Kaigai Shinshutsu Kigyou Souran, published in Japanese by the Toyou Keizai publishing company of Japan. This source provides comprehensive data on FDI activity at the firm level. Japanese FDI in the U.S. (as opposed to FDI from other significant source countries) is of particular interest, because it changed so dramatically over the course of the 1980s. A large number of Japanese multinationals shifted from a position of very limited direct investment (or no direct investment) in the U.S. at the beginning of my sample period to a position of "substantial" direct investment by the end. This large change may help identify the parameters of interest. The unit of analysis in the Kaigai Shinshutsu Kigyou Souran data source is that of the enterprise or business. Some of these acquired or established enterprises contain several plants and large numbers of employees. Other acquired or established firms are smaller. In principle, one might want to weight counts of acquired or established enterprises by the size of these enterprises. In practice that is difficult, as the data on employment or sales of U.S. affiliates of Japanese firms are not recorded with consistency. Branstetter (2000) uses an alternative data source on Japanese FDI that has more consistent measures of size, although this source looks only at manufacturing establishments - distribution centers and R\&D facilities are not included. Empirical results suggest size-weighted counts of affiliates or counts of employees yield results that are no better than those obtained using simple counts of affiliates.

Data on parent firms' sales and industry affiliation were taken from the Japan Development Bank Corporate Finance database. Data on the R\&D spending of Japanese firms were taken primarily from survey data published (in Japanese) in the Kaisha Shiki Ho quarterly series of reports on Japanese publicly traded firms. Data on the U.S. patenting of Japanese firms were taken from the CASSIS CD-ROM published by the U.S. patent office and later matched to patent data in the REI database at Case-Western 
Reserve University. This amounted to hundreds of thousands of patents and even larger numbers of citations. The years of my sample period are 1981 through 1994.

This study uses data on the U.S. patents of 187 Japanese firms (an unbalanced panel) and the universe of "American" inventors, as determined by the address of the first listed inventor. Of course, some "American" inventors work for Japanese firms or the subsidiaries of Japanese firms. These inventors are specifically excluded from the sample of "American" patents in the specifications reported in Tables 4 and 5, as is indicated in the text. "American" inventors working for non-U.S. multinationals are considered "American" for the purposes of this study. ${ }^{35}$ Conversely, foreign inventors (that is, inventors with a nonU.S. address) working for U.S. firms are not counted as part of the body of "American" inventors. This is intentional, in that the purpose of this study is to examine the impact of the geographic proximity conferred by FDI in the U.S. on spillovers to and from inventive activity physically located in that country. It is also worth noting that the vast majority of R\&D activity conducted by U.S. multinationals is undertaken within the boundaries of the United States.

For this study, there was really no alternative to the use of data on Japanese firms' U.S. patents, as it has proven impossible to date to obtain reliable information on the citations in Japanese patent applications. This, in part, stems from the very different set of legal requirements for citation that firms have faced under Japanese patent law. Nevertheless, interviews with leading Japanese firm executives and empirical studies such as Branstetter and Sakakibara (1998) and Sakakibara and Branstetter (1999) suggest that Japanese firms seek to patent all their valuable ideas in both the U.S. and Japan, so that trends in their U.S. patents should be reflective of their total innovative activity. Note that Japanese firms are by far the most important foreign users of the U.S. patent system, accounting for roughly one quarter of all patents granted by the U.S. during the latter 1980s and early 1990s.

\section{Results of Alternative Linear Specifications}

In Table A, I present linear results with a transformed dependent variable. While the count data models used in the text of the paper are arguably more appropriate than a linear model, given the "count"

${ }^{35}$ To be more precise, "American" inventors who produce patents assigned to the investing Japanese parent company are always considered to be "Japanese." Americans working for "native" enterprises that are subsequently acquired by Japanese firms are considered "American" in Tables 2 and 3 of the paper, and in Tables A and B of this Data Appendix. However, all patents produced by these firms are excluded from the analysis presented in Tables 4 and 5 of the paper. 
nature of the dependent variable, a linear specification may provide a useful "benchmark" against which the results in the paper can be compared. The estimating equation used is:

$$
c_{J i t}=\beta_{0}+\beta_{1} p_{i t-1}+\beta_{2} F D I_{i t}+\beta_{3} r_{i t}+\sum_{c} \delta_{c} D_{c}+\sum_{t} \alpha_{t} T_{t}+\alpha_{i}+\varepsilon_{i t}
$$

In all specifications, real sales is added as an additional control variable.

In the fixed effects results, the impact of "acquisition" FDI is positive and significant. The impact of FDI by other measures is generally not statistically significant. ${ }^{36}$ The designation of specifications as (1), (2), and (3) refers to three alternative measures of FDI, following the convention established in the text of the paper. (1) counts the cumulative sum of total affiliates, regardless of the means of establishment or the purpose of the affiliate. (2) counts only the cumulative sum of affiliates obtained through acquisition. (3) counts only the cumulative sum of affiliates whose "statement of business purpose" in the FDI data base explicitly identifies it as an overseas R\&D facility. Although not shown in the table, I experimented with various lags of the FDI variables. I found the results of the lags were qualitatively similar to, but statistically weaker than the results of contemporaneous count measures. This may indicate that spillovers occur almost immediately after the acquisition or "greenfield" establishment takes place.

The interpretation of the coefficient on the FDI terms is the percentage increase in "spillovers" (as measured by citations) that results from an additional affiliate. Thus, even small coefficients can be indicative of fairly large effects. The coefficient in the fifth column, for instance, suggests that a firm that made three acquisitions would increase the flow of spillovers by more than $30 \%{ }^{37}$

In Table B, where I look at citations by U.S. inventors to the Japanese investing firms, I find in all specifications a positive relationship between FDI and spillovers from the Japanese firms to U.S. inventors. Recall that the estimating equation is:

$$
c_{A i t}=\beta_{0}+\beta_{1} p_{i t}+\beta_{2} F D I_{i t}+\beta_{3} r_{i t}+\sum_{c} \delta_{c} D_{c}+\sum_{t} \alpha_{t} T_{t}+\alpha_{i}+\varepsilon_{i t}
$$

\footnotetext{
36 Note that this pattern of results is different from that obtained using Poisson and Negative Binomial models. The difference may be due to the transformation of the dependent variable that is required to get linear models to "work" in this context. See the discussion on the next page.

37 Of course, this discussion of interpretation begs the question of whether the impact of additional affiliates is really constant. This is a question which can be investigated with the available data. Such investigation is the subject of ongoing research.
} 
In all specifications, sales is used as an additional control. ${ }^{38}$ The positive relationship between citations and FDI holds regardless of the exact measure of FDI used. The table shows only the results of regressions with contemporaneous measures of FDI, but the results tend to be qualitatively similar and statistically stronger if the measures of FDI are lagged by one or two periods. Again, the coefficients suggest the cumulative effect of a large increase in the number of affiliates could be quite substantial. There is no support in this specification for the notion that greenfield investment should be encouraged while acquisition should be shunned because it leads to a one-way flow of spillovers back to Japan. If anything, the fixed effects results suggest acquired firms are a more effective channel of spillover to the U.S. than newly established enterprises or even R\&D facilities.

However, these linear results need to be viewed with some caution. For a large number of observations, the realization of the dependent variable is zero. The effects of the transformation required to make these observations "work" in a log-linear framework may lead to bias. Fortunately, the econometrics of "count data" is now fairly well developed. It is possible to estimate fixed-effects versions of the Poisson and Negative Binomial models. This is the approach taken in the text of the paper. ${ }^{39}$

\section{Sketch Derivation of Poisson and Negative Binomial Regression Models}

Here, I summarize the results of the derivation of count data estimators by Hausman, Hall, and Griliches (1984). The notation below borrows extensively from the presentation of these basic results found in Montalvo and Yafeh (1994).

The Poisson estimator posits a relationship between the dependent and independent variables such that

$$
\operatorname{pr}\left(n_{i t}\right)=f\left(n_{i t}\right)=\frac{e^{-\lambda_{i t}} \lambda^{n i t}{ }_{i t}}{n_{i t} !}
$$

where $\lambda_{i t}=e^{X_{i t} \beta}$

Econometric estimation is possible by estimating the log likelihood function using standard maximum likelihood techniques. The negative binomial estimator generalizes the Poisson by allowing an additional

\footnotetext{
${ }^{38}$ Recall that here, $p_{i t}$ refers to the cumulated stock rather than the contemporaneous flow of patents of firm $i$ in year $t$.

${ }^{39}$ Note that the number of observations is larger in Table A and Table B than in the tables given in the paper. This is because the fixed effects Poisson estimator automatically drops all observations for firms whose citations never vary from zero. In addition, in Tables 4 and 5 I introduce additional control variables which are not available for all firms in all years.
} 
source of variance. I allow the Poisson parameter $\lambda$ to be randomly distributed according to a gamma distribution. Thus defining $\lambda$ as before

$\lambda_{i t}=e^{X_{i t} \beta}+\varepsilon_{i}$

Using the relationship between the marginal and conditional distributions, I can write

$\operatorname{Pr}\left[N_{i t}=n_{i t}\right]=\int \operatorname{Pr}\left[N_{i t}=n_{i t} \mid \lambda_{i t}\right] f\left(\lambda_{i t}\right) d \lambda_{i t}$

If the density function is assumed to follow a gamma distribution, then the Poisson model becomes a

Negative Binomial model:

$\lambda_{i t}=\Gamma\left(\alpha_{i t} \varphi_{i t}\right)$

where

$\alpha_{i t}=e^{X_{i t} \beta}$

then

$\operatorname{Pr}(n)=\int_{0}^{\infty} \frac{e^{-\lambda_{i t}} \lambda_{i t}}{n_{i t} !} \frac{\lambda_{i t}^{-1}}{\Gamma\left(\varphi_{i t}\right)}\left[\frac{\varphi_{i t} \lambda_{i t}}{\alpha_{i t}}\right]^{\phi_{i t}} e^{\phi_{i t} \lambda_{i t} \int \alpha_{i t}} d \lambda_{i t}$

where

$E\left(\lambda_{i t}\right)=\alpha_{i t} V\left(\lambda_{i t}\right)=\frac{\alpha_{i t}^{2}}{\phi_{i t}}$

Integrating by parts and using the fact that

$\Gamma(\alpha)=\alpha \Gamma(\alpha-1)=(\alpha-1) !$

yields the following distribution

$\operatorname{Pr}\left(n_{i t}\right)=\frac{\Gamma\left(n_{i t}+\phi_{i t}\right)}{\Gamma\left(n_{i t}+1\right) \Gamma\left(\phi_{i t}\right)}\left[\frac{\phi_{i}}{\alpha_{i t}+\phi_{i t}}\right]^{\phi_{i t}}\left[\frac{\alpha_{i t}}{\phi_{i t}+\alpha_{i t}}\right]^{n_{i t}}$

with

$E\left(n_{i t}\right)=\alpha_{i t}$

and

$V\left(n_{i t}\right)=\alpha_{i t}+\alpha_{i t}^{2} / \phi_{i t}$ 
This can also be estimated using maximum likelihood techniques. The log likelihood function becomes

$$
L(\beta)=\sum_{i} \sum_{t} \log \Gamma\left(\lambda_{i t}+n_{i t}\right)-\log \Gamma\left(\lambda_{i t}\right)-\log \Gamma\left(n_{i t}+1\right)+\lambda_{i t} \log (\delta)-\left(\lambda_{i t}+n_{i t}\right) \log (1+\delta)
$$

with

$$
V\left(n_{i t}\right)=e^{X_{i t} \beta}(1+\delta) / \delta
$$

Thus, the coefficients are estimated using standard maximum likelihood techniques.

From here, we can proceed to a sketch derivation of the "conditional" or "fixed-effects" negative binomial estimator. The derivation and the notation closely follow Hausman, Hall, and Griliches (84), and the presentation here is meant only to summarize their work. For more details, the reader is referred to their paper.

Let the moment generating function for the negative binomial distribution be

$$
m(t)=\left(\frac{1+\delta+e^{l}}{\delta}\right)^{-\gamma}
$$

Now consider a simple case with two observations. If $\gamma$ is common for two independent negative binomial random variables $\mathrm{w}_{1}$ and $\mathrm{w}_{2}$, then $\mathrm{w}_{1}+\mathrm{w}_{2}=\mathrm{Z}$ is distributed as a negative binomial with parameters $\left(\gamma_{1}+\gamma_{2}, \delta\right)$. This is due to the fact that the moment generating function of a sum of independent random variables equals the product of their moment generating functions. We derive the distribution for the two observations case.

$$
\begin{aligned}
& \operatorname{pr}\left(w_{1} \mid z=w_{1}+w_{2}\right)=\frac{\operatorname{pr}\left(w_{1}\right) \operatorname{pr}\left(z-w_{1}\right)}{\operatorname{pr}(z)} \\
& =\frac{\frac{\Gamma\left(\gamma_{1}+w_{1}\right)}{\Gamma\left(\gamma_{1}\right) \Gamma\left(w_{1}+1\right)}(1+\delta)^{-\left(w_{1}+w_{2}\right)}\left(\frac{\delta}{1+\delta}\right)^{\gamma_{1}+\gamma_{2}} \frac{\Gamma\left(\gamma_{2}+w_{2}\right)}{\Gamma\left(\gamma_{2}\right) \Gamma\left(w_{2}+1\right)}}{\frac{\Gamma\left(\gamma_{1}+\gamma_{2}+z\right)}{\Gamma\left(\gamma_{1}+\gamma_{2}\right) \Gamma(z+1)}(1+\delta)^{-z}\left(\frac{\delta}{1+\delta}\right)^{\gamma_{1}+\gamma_{2}}} \\
& =\frac{\Gamma\left(\gamma_{1}+w_{1}\right) \Gamma\left(\gamma_{1}+w_{2}\right) \Gamma\left(\gamma_{1}+\gamma_{2}\right) \Gamma\left(w_{1}+w_{2}+1\right)}{\Gamma\left(\gamma_{1}+\gamma_{2}+z\right) \Gamma\left(\gamma_{1}\right) \Gamma\left(\gamma_{2}\right) \Gamma\left(w_{1}+1\right) \Gamma\left(w_{2}+1\right)}
\end{aligned}
$$


Here each firm can have its own $\delta$ so long as this $\delta$ does not vary over time. The $\delta$ has been eliminated by the conditioning argument. More generally, considering the joint probability of a given firm's citations conditional on the multi-year total, we can obtain the following distribution.

$$
\operatorname{pr}\left(n_{i 1}, \ldots, n_{i T} \mid \sum n_{i t}\right)=\left(\prod_{t} t \frac{\Gamma\left(\gamma_{i t}+n_{i t}\right)}{\Gamma\left(\gamma_{i t}\right) \Gamma\left(n_{i t}+1\right)}\right)\left(\frac{\Gamma\left(\sum_{t} \gamma_{i t}\right) \Gamma\left(\sum_{t} n_{i t}+1\right)}{\Gamma\left(\sum_{t} \gamma_{i t}+\sum_{t} n_{i t}\right.}\right)
$$

Given this, we are able to do estimation of the following log likelihood function

$$
\begin{aligned}
& \log L=\sum_{i} \sum_{t} \log \Gamma\left(\lambda_{i t}+n_{i t}\right)-\log \Gamma\left(\lambda_{i t}\right)-\log \Gamma\left(n_{i t}+1\right)+\log \Gamma\left(\sum_{t} \lambda_{i t}\right)+ \\
& \log \Gamma\left(\sum_{t} n_{i t}+1\right)-\log \Gamma\left(\sum_{t} \lambda_{i t}+\sum_{t} n_{i t}\right)
\end{aligned}
$$

where

$$
\lambda_{i t}=e^{X_{i t} \beta}
$$


Table A Spillovers to Investing Japanese Firms Linear Regressions

Dependent Variable: $\log ($ citations) $\mathrm{Obs}=\mathbf{2 1 2 0}$

\begin{tabular}{|c|c|c|c|c|c|c|}
\hline & $\begin{array}{c}\text { Random } \\
\text { Effects (1) }\end{array}$ & $\begin{array}{l}\text { Random } \\
\text { Effects(2) }\end{array}$ & $\begin{array}{c}\text { Random } \\
\text { Effects(3) }\end{array}$ & $\begin{array}{l}\text { Fixed } \\
\text { Effects (1) }\end{array}$ & $\begin{array}{l}\text { Fixed } \\
\text { Effects(2) }\end{array}$ & $\begin{array}{l}\text { Fixed } \\
\text { Effects(3) }\end{array}$ \\
\hline $\log R \& D$ & $\begin{array}{c}.0394 \\
(.0319)\end{array}$ & $\begin{array}{c}.0412 \\
(.0321)\end{array}$ & $\begin{array}{c}.0406 \\
(.0319)\end{array}$ & $\begin{array}{c}.1187 \\
(.0461)\end{array}$ & $\begin{array}{c}.1188 \\
(.0460)\end{array}$ & $\begin{array}{c}.1190 \\
(.0461)\end{array}$ \\
\hline log sales & $\begin{array}{c}.1042 \\
(.0428)\end{array}$ & $\begin{array}{c}.0941 \\
(.0423)\end{array}$ & $\begin{array}{c}.0949 \\
(.0424)\end{array}$ & $\begin{array}{c}.1879 \\
(.1030)\end{array}$ & $\begin{array}{c}.1981 \\
(.1029)\end{array}$ & $\begin{array}{c}.1877 \\
(.1042)\end{array}$ \\
\hline log U.S. patents & $\begin{array}{c}.9572 \\
(.0166)\end{array}$ & $\begin{array}{c}.9518 \\
(.0167)\end{array}$ & $\begin{array}{c}.9541 \\
(.0167)\end{array}$ & $\begin{array}{l}.6012 \\
(.0285)\end{array}$ & $\begin{array}{c}.5911 \\
(.0286)\end{array}$ & $\begin{array}{c}.5997 \\
(.0285)\end{array}$ \\
\hline U.S. FDI & $\begin{array}{l}-.0119 \\
(.0086)\end{array}$ & $\begin{array}{r}.0175 \\
(.0388)\end{array}$ & $\begin{array}{l}-.0035 \\
(.0192)\end{array}$ & $\begin{array}{l}-.0081 \\
(.0107)\end{array}$ & $\begin{array}{c}.1057 \\
(.0048)\end{array}$ & $\begin{array}{l}-.0070 \\
(.0225)\end{array}$ \\
\hline Industry Dummies & Yes & Yes & Yes & N.A. & N.A. & N.A. \\
\hline Time Dummies & Yes & Yes & Yes & Yes & Yes & Yes \\
\hline
\end{tabular}

(1) Indicates FDI measured as cumulative counts of all U.S. subsidiaries.

(2) Indicates FDI measured as cumulative counts of acquired U.S. subsidiaries.

(3) Indicates FDI measured as cumulative counts of U.S. R\&D/product development facilities. 
Table B Spillovers from Investing Japanese Firms

Linear Regressions

Dependent Variable: $\log ($ citations $)$ Obs $=2120$

\begin{tabular}{|c|c|c|c|c|c|c|}
\hline & $\begin{array}{c}\text { Random } \\
\text { Effects (1) }\end{array}$ & $\begin{array}{l}\text { Random } \\
\text { Effects (2) }\end{array}$ & $\begin{array}{c}\text { Random } \\
\text { Effects(3) }\end{array}$ & $\begin{array}{l}\text { Fixed } \\
\text { Effects }(1)\end{array}$ & $\begin{array}{l}\text { Fixed } \\
\text { Effects (2) }\end{array}$ & $\begin{array}{l}\text { Fixed } \\
\text { Effects(3) }\end{array}$ \\
\hline $\log R \& D$ & $\begin{array}{c}.0593 \\
(.0254)\end{array}$ & $\begin{array}{c}.0556 \\
(.0257)\end{array}$ & $\begin{array}{l}.0617 \\
(.0255)\end{array}$ & $\begin{array}{c}.0332 \\
(.0274)\end{array}$ & $\begin{array}{c}.0277 \\
(.0276)\end{array}$ & $\begin{array}{c}.0341 \\
(.0275)\end{array}$ \\
\hline log sales & $\begin{array}{c}.1885 \\
(.0399)\end{array}$ & $\begin{array}{c}.2260 \\
(.0398)\end{array}$ & $\begin{array}{c}.1847 \\
(.0400)\end{array}$ & $\begin{array}{c}.0573 \\
(.0610)\end{array}$ & $\begin{array}{c}.1012 \\
(.0615)\end{array}$ & $\begin{array}{c}.0358 \\
(.0621)\end{array}$ \\
\hline log U.S. patents & $\begin{array}{c}.6066 \\
(.0151)\end{array}$ & $\begin{array}{c}.6096 \\
(.0152)\end{array}$ & $\begin{array}{c}.6154 \\
(.0149)\end{array}$ & $\begin{array}{c}.4769 \\
(.0205)\end{array}$ & $\begin{array}{c}.4740 \\
(.0182)\end{array}$ & $\begin{array}{c}.4879 \\
(.0206)\end{array}$ \\
\hline U.S. FDI & $\begin{array}{c}.0397 \\
(.0062)\end{array}$ & $\begin{array}{c}.0623 \\
(.0279)\end{array}$ & $\begin{array}{c}.0733 \\
(.0132)\end{array}$ & $\begin{array}{c}.0421 \\
(.0063)\end{array}$ & $\begin{array}{c}.0839 \\
(.0287)\end{array}$ & $\begin{array}{c}.0644 \\
(.0134)\end{array}$ \\
\hline Industry Dummies & Yes & Yes & Yes & N.A. & N.A. & N.A. \\
\hline Time Dummies & Yes & Yes & Yes & Yes & Yes & Yes \\
\hline
\end{tabular}

(1) Indicates FDI measured as cumulative counts of all U.S. subsidiaries.

(2) Indicates FDI measured as cumulative counts of acquired U.S. subsidiaries.

(3) Indicates FDI measured as cumulative counts of U.S. R\&D/product development facilities. 